\title{
Ampulla of Vater Mixed Adenoneuroendocrine Carcinoma
}

National Cancer Institute

\section{Source}

National Cancer Institute. Ampulla of Vater Mixed Adenoneuroendocrine Carcinoma. NCI

Thesaurus. Code C95986.

A carcinoma that arises from the ampulla of Vater and the periampullary region. It is characterized by the presence of a malignant glandular epithelial component and a malignant neuroendocrine component. At least 30 percent of either component should be present for the diagnosis to be made. 